\title{
A KATONAI KOGNITÍV INTELLIGENCIA FEJLESZTÉSÉNEK LEHETŐSÉGEI MESTERSÉGES INTELLIGENCIA ALKALMAZÁSÁVAL
}

\author{
DOI: $10.35926 / \mathrm{HSZ} .2021 .6 .4$
}

ÖSSZEFOGLALÓ: A következő generáció mesterséges intelligenciájának már úgy kell kölcsönhatásba lépnie a felhasználókkal, hogy meggyőzzék őket abban, hogy képesek megérteni az emberi elméket, beleértve az érzelmeket is. Ehhez mesterséges érzelmi intelligenciára van szükség, amely képes a társadalmi érzelmi interakciókban megfelelö, hihető viselkedésre. A tanulmány az ilyen típusú mesterséges intelligenciák lehetséges katonai hasznositásáról szól.

KULCSSZAVAK: mesterséges intelligencia, társadalom, kognitív intelligencia, katonai kutatások

\section{BEVEZETÉS}

Nem túlzás azt állítani, hogy manapság a mesterséges intelligencia (MI) vizsgálata a kutatások egyik legfontosabb területévé vált. Növekvő népszerüsége elsősorban az új gépi tanulási technikáknak, valamint a folyamatosan és gyorsan növekvő számítási sebességeknek köszönhető, amelyek korábban elképzelhetetlen képességek létrehozását teszik lehetővé. Mégis valami sokkal nagyobb dolog várható a közeljövőben. Azok a kihívások, amelyek eddig csak álmok voltak, ma érthetővé és megoldhatóvá válnak. A témával már több írásomban foglalkoztam, ${ }^{1}$ ebben a publikációban jelentős részben az amerikai hadsereg által közzétett, nyílt anyagként elérhető kutatási összefoglalót használtam fel. ${ }^{2}$

1 Dr. Négyesi Imre: A mesterséges intelligencia katonai felhasználásának társadalmi kérdései. Honvédségi Szemle, 2021/1., 133-144. https://kiadvany.magyarhonvedseg.hu/index.php/honvszemle/article/view/199; Porkoláb Imre - Négyesi Imre: A mesterséges intelligencia alkalmazási lehetőségeinek kutatása a haderőben. Honvédségi Szemle, 2019/5., 3-19. https://honvedelem.hu/images/media/5f2bd1646eeb8298912683.pdf; Dr. Négyesi Imre: A mesterséges intelligencia és a hadsereg. Hadtudomány, 2019/3., 71-79. https://www.mhtt.eu/ hadtudomany/2019/2019_3/2019eA\%20mesterséges\%20intelligencia\%20és\%20a\%20hadseregek_Négyesi\%20 Imre.pdf; Dr. Négyesi Imre: A mesterséges intelligencia és az etika. Hadtudomány, 2020/1., 103-113. http://mhtt. eu/hadtudomany/2020/2020_1szam/Hadtudomany_2020-1-szam.pdf (Letöltések időpontja: 2021. 01. 05.)

2 Tad T. Brunyé et al.: A Review of US Army Research Contributing to Cognitive Enhancement in Military Contexts. Journal of Cognitive Enhancement, Vol. 4, 12. 02. 2020., 453-468. https://link.springer.com/article/10.1007/ s41465-020-00167-3 (Letöltés időpontja: 2021. 01. 05.) 


\section{AZ EMBERI INTELLIGENCIA ÉS A MESTERSÉGES INTELLIGENCIA KAPCSOLATA}

Tanulmányomban a kognitív intelligenciával foglalkozom, ezen belül is elsősorban a katonai kognitív teljesítmény növelésének lehetőségeivel és az MI kapcsolatával. Először áttekintem, hogy jelenleg milyen fö kihívások foglalkoztatják a kutatókat, amelyekre az elkövetkező években várhatóan sikerül megoldást találni, és amelyek hatással lehetnek a katonai kognitív képességek fejlesztési lehetőségeire is. A kiindulási alapot az emberi intelligencia jelenti, hiszen ez lesz a „minta” az MI számára. Alapértelmezésben az intelligenciának három szintjét különböztethetjük meg:

- a számítási intelligencia szintje (a gyors számítás és a memória képessége);

- a perceptuális (észlelési) intelligencia szintje (a látás érzékelési képessége, a hallás és az érintés, beleértve a számítógépes látást, a beszédfelismerést, a nyelvtudást és a fordítást);

- a kognitív intelligencia szintje (a megértés, a reagálás képessége, az érvelés és a döntéshozatal).

Ebben az írásomban a kognitív intelligencia szintjét vizsgálom a katonai intelligencia szempontjából, ahol az első kihívás az ,emberszintu”” mesterséges érzelmi intelligencia megalkotása. A cél az, hogy az emberekkel kölcsönhatásban álló gépek az érzelmeket is használják döntéshozatalukhoz és viselkedésük generálásához. Ez teheti lehetővé számukra, hogy az emberi kapcsolatokhoz hasonlóan az MI-k is hosszú távú társadalmi kapcsolatokat alakítsanak ki az emberekkel, minden jogi és etikai következménnyel, amelyek ma egyre nagyobb figyelmet érdemelnek. Ezáltal képesek motiválni cselekedeteiket és döntéseiket, a célok és a tanulási célok megválasztását. Ezért az érzelmi intelligencia a kulcs a többi kihívás megválaszolásához. Ez nem csak az érzelmek felismerésének és kifejezésének a képességében rejlik, amely kérdésre jelenleg a legtöbb kutatás, így a katonai kutatások is irányulnak. Bár mindkét képességre szükség van, sokkal fontosabb és nehezebb megérteni az összekötő részt, az érzelmi intelligenciát önmagában.

A második kihívás úgy definiálható, mint egy cél a történések összefüggéseinek megértésére. Ez gyakorlatilag azt jelenti, hogy a rendelkezésre álló információk alapján az MI-nek önállóan kell feldolgoznia és folyamatosan frissítenie a múlt és a jövő eseményeit, meg kell határoznia abban betöltött szerepét, majd konkrét célokat kell kitüznie és ezek alapján terveket kell kidolgoznia a célok eléréséhez. ${ }^{3}$

A harmadik kihívást az emberéhez hasonló aktív tanulás megvalósítása jelenti. Az MI - hasonlóan egy személyhez - olyan értékrendszert alakít ki, amely motiválja a tanulási folyamatát. Ez az értékrend segít a tanulónak abban, hogy eszközöket - például kísérleteket válasszon a hipotézisek teszteléséhez, az elérhető források online kereséséhez vagy egy személy megkérdezéséhez. Az MI saját kezdeményezésre keresi ezeket az eszközöket tanulási céljainak elérése érdekében. Ebben az esetben az MI képes lesz autonóm módon felnőni, kezdve a gyermeki szinttől az emberi felnőtt szintjéig - és azon túl is. Ezt a képességet nevezhetjük „emberszintü tanulási intelligenciának” - megkülönböztetve a „mély tanulástól” és a gépi tanulás egyéb, ma népszerü formáitól.

A kiinduló feltételezés az, hogy egy robot képes lehet minderre. Mi hiányzik még a robotból az emberhez képest? Először is az emberihez hasonló szabad akarat, érzelmesség és társas kapcsolat felnőttszintű kezelésének képessége - például a humorérzék. Hiányzik

3 Ezt a képességet „narratív intelligenciának” hívják. 
továbbá az a képesség, hogy korlátozások nélkül növekedjen értelmileg és érzelmileg is. De ami a legfontosabb, hiányzik belőle egy „emberi lélek”, amely képes másokra gondolni, álmokban és emlékekben élni; kívülről látja önmagát, és a mindennapi feladatok nyüzsgése felett áll. Ez a képesség áll az emberi elme felépítésének csúcsán, kezeli az emberi képességeket és meghatározza az önkéntes viselkedést. Ha azt akarjuk, hogy a robot olyan legyen, mint egy ember, akkor a robotnak olyan „lélekre” van szüksége, amely felelős a kognitív és az intellektuális képességeiért.

A leírtak összefoglalásaként megállapítható, hogy eddig a kutatók az MI-vel kapcsolatban olyan megoldások keresésével voltak elfoglalva, amelyek lehetővé tehetik az MI számára problémák megoldását és döntések meghozatalát, adatok elemzését, konkrét dolgok megtanulását, a természetes nyelv megértését és használatát, a világról való tudás felhalmozását. Tehát látni, hallani, irányítani a mozgásokat, kidolgozni a forgatókönyveket, utánozni a kreativitást, önállóan új célokat kitüzni - vagy jelezni, hogy nem hajlandó teljesíteni a parancsokat. A fö kérdés tehát az, hogy miként lehet elérni a robot ilyen szintü „emberiesítését”. Kutatók szerint a fő kulcs az általános célú emberszintű szociális-érzelmi intelligencia. A jelenség elméletének kidolgozása és empirikus validálása létfontosságú és elkerülhetetlen, ha egy erős „emberszerü” mesterséges intelligenciát akarunk felépíteni.

\section{A KATONAI KOGNITÍV KÉPESSÉGEK FEJLESZTÉSE}

Ebben a fejezetben áttekintem, hogy milyen lépések történtek eddig a katonai kognitív képességek fejlesztésének területén. Irányadó példaként az Amerikai Egyesült Államok Védelmi Minisztériumának tevékenységét tekintettem, beleértve a hadsereget, a légierőt, a haditengerészetet is. A Fejlett Védelmi Kutatási Projektek Ügynöksége (DARPA $\left.{ }^{4}\right)$ tevékenységét is érdemes figyelembe venni, mert már több mint fél évszázada kognitív fejlesztési kutatással is foglalkozik, valamint új gyógyszerészeti, étrendi, idegtudományi, oktatási, technológiai és az alvással kapcsolatos fejlesztési stratégiákat dolgoz ki.

A jelenleg is folyó kutatói munkának az átfogó célja olyan biztonságos, megbízható és robusztus stratégiák és technológiák meghatározása, amelyek segítik a katonai személyzet eröfölényének elérését a fokozott készségszerzés, az éberség és a fenyegetések felderítése, a helyzetfelismerés, a döntéshozatal, a csapatmunka és az érzelmi ellenőrzés révén. Az Amerikai Egyesült Államok haderejének legújabb kutatásai a kognitív fejlesztés számos megközelítését vizsgálják. Idetartoznak olyan megközelítések, amelyek kifejezetten a feladatok fokozottabb teljesítéséért közvetlenül felelős neurális mechanizmusokat és folyamatokat célozzák meg, és magukban foglalják a transzkraniális elektrostimulációt $\left(\mathrm{tES}^{5}\right)$, a kiterjesztett valóságot $\left(\mathrm{AR}^{6}\right)$ és a célzott készségfejlesztést.

Az Amerikai Egyesült Államokban az emberi kognitív teljesítmény fokozását célzó kutatás és fejlesztés kiemelt terület a Védelmi Minisztérium számos szolgálata és ügynöksége számára, beleértve a hadsereget, a légierőt, a haditengerészetet és a DARPA-t. A haderőn belül a kognitív fejlesztés kutatását elsősorban a modernizációval foglalkozó parancsnokság beosztott szervezetei irányítják. Ezek a szervezetek magukban foglalják a hadsereg Viselkedés- és Társadalomtudományi Kutatóintézetét $\left(\mathrm{ARI}^{7}\right)$, a Harcképességek Fejlesztési

\footnotetext{
4 Defense Advanced Research Projects Agency.

Transcranial Electrical Stimulation.

Augmeneted Reality.

Behavioral and Social Sciences.
} 
Parancsnoki Központját (CCDC SC ${ }^{8}$, az Adat- és Elemzőközpontot (CCDC DAC ${ }^{9}$ ), a hadsereg Kutatólaboratóriumát (CCDC $\mathrm{ARL}^{10}$ ) és a Fegyverkezési Központot (CCDC $\mathrm{AC}^{11}$ ). Idetartoznak az Orvosi Kutatási és Fejlesztési Parancsnokság (MRDC ${ }^{12}$ ) laboratóriumai is, beleértve a haderő Környezetgyógyászati Kutatóintézetét (USARIEM ${ }^{13}$ ), az amerikai hadsereg Repüléstechnikai Kutatólaboratóriumát (USAARL ${ }^{14}$ ) és a hadsereg Walter Reed Kutatóintézetét (WRAIR ${ }^{15}$ ).

Ezeknek a szervezeteknek együttesen több mint 15 ezer tudósa és mérnöke van, közülük sokan a katona kognitív teljesítményének növelését célzó megoldásokat hoznak létre, integrálnak és alkalmaznak. A kutatás-fejlesztés általános célja a katonai erőfölény elérése és fenntartása képességének a növelése például gyorsított kiképzés és készségszerzés, célzott értékelés és visszacsatolás, valamint fokozott éberség, fenyegetésészlelés, helyzetfelismerés, döntéshozatali csapatmunka és érzelmi ellenőrzés révén. E kutatási témák sokféleségére és összetettségére tekintettel a legtöbb védelmi kutatócsoport eredendően multidiszciplináris, átfogja a kognitív, az affektív, a társadalomtudományi és a viselkedéstudományi területeket, valamint felhasználja a robotika, az informatika és az orvosbiológiai mérnöki szakértelmet. Az amerikai hadsereg kutatásának és fejlesztésének jelentős részét a védelmi szféra tudósai és mérnökei végzik, de mindegyik szervezet évente vagy félévente kérelmeket intéz tudományos szervezetekhez és az ipar szereplöihez, hogy segítsék a munkájukat.

A kutatás fontosságát nemcsak a felsorolt sok szervezet és a nagy létszámú kutatószemélyzet jelzi, hanem a kutatási témák sokrétüsége is, ami az amerikai haderő által finanszírozott sokféle alap- és alkalmazott kutatási programhoz vezet. A kutatási témák közül kiemelek néhányat, amelyek elsődleges hangsúlyt fektetnek a kognitív fejlesztésre. A témák leírásakor az eredeti angol megnevezést használtam, mert a magyar fordítás nem minden esetben határozza meg pontosan a téma tartalmát, de az a célok rövid meghatározásában megtalálható:

- Measuring and Advancing Soldier Tactical Readiness and Effectiveness (MASTR-E) - Célok: a katonák taktikai felkészültségének és hatékonyságának mérése és elősegítése, valamint a katonák fegyverhasználatának, mozgatásának, kommunikációjának és döntési képességeinek javítása;

- Biomedical Performance Enhancement - Célok: orvosbiológiai teljesítménynövelés, orvosbiológiai stratégiák kidolgozása, validálása és terjesztése az egyéni harcosok egészségének és felkészültségének - ideértve a kognitív funkciókat is - javítása érdekében;

- Team Overmatch Program - Célok: a kognitív teljesítményt negatívan befolyásoló egészségtelen stressz-szintek megelőzése, valamint az ellenálló képesség és a helyzettudat javítása;

- Continuous Multi-faced Soldier Characterization for Adaptive Technologies (CMSCAT) - Célok: a külső tényezők befolyása a katonák teljesítményére, analitikai

\footnotetext{
${ }^{8}$ Combat Capabilities Development Command Soldier Center.

9 Data \& Analysis Center.

${ }_{10}$ Army Research Laboratory.

11 Armaments Center.

12 Medical Research and Development Command.

${ }^{13}$ US Army Research Institute of Environmental Medicine.

14 US Army Aeromedical Research Laboratory.

15 Walter Reed Army Institute of Research.
} 
technikák segítségével valós idejü adaptív technológiák kidolgozása a teljesítménynövelés érdekében;

- Restorative Sleep for Performance and Health (RSPH) - Célok: az alvás helyreállító előnyeinek megértése és előrejelzése, valamint a helyreállító alvás megkönnyítése a teljesítmény javítása érdekében;

- Physiological Basis of Resilience - Célok: olyan fiziológiai mutatók meghatározása, amelyek előre jelzik a katonák stressz-szintjét, valamint fokozzák a fizikai, érzelmi és viselkedési funkciókat.

Ezek a témák a kognitív teljesítmény fokozására összpontosítanak, de fontos megkülönböztetni a teljesítménynövelést az optimalizálástól. A teljesítmény optimalizálása a hadseregekben gyakran olyan technológiák és technikák alkalmazásával jár, amelyek célja az egyének és a csapatok csúcsteljesítményének fenntartása a környezeti vagy feladattal kapcsolatos zavarok ellenére. A kognitív teljesítményoptimalizálási stratégiák rövid és hosszú távon pontos irányítással, kombinációval és alkalmazással érhetik el ugyanazokat a célokat. Például a valós idejü helyfrissítések rendelkezésre bocsátása nehezen érzékelhető célpontok esetében segíthet a katonai személyzet számára a lövészi teljesítmény optimalizálásában a pontosság és a hatékonyság fenntartása mellett stressz, terhelés és bizonytalanság esetén.

Ezzel szemben a teljesítménynövelés magában foglalja az egyén és a csapat teljesítményének a meglévő csúcsképességeken túli felgyorsítását vagy felerősítését, valójában a teljesítményeloszlás megváltoztatását. Ez a meghatározás összhangban áll a Bostrom és Sandberg által javasolt definícióval. ${ }^{16}$ Ök a kognitív fejlesztést úgy határozták meg, hogy ,, az elme alapvető képességeinek felerösitése vagy kiterjesztése a belső vagy külső információfeldolgozó rendszerek fejlesztésével vagy bövitésével". A kognitív fejlesztéssel elért minden új teljesítményszint az egyének új személyes csúcspontjává válik, emelve a jövőbeni teljesítmény színvonalát. Fontos, hogy mind az optimalizálás, mind a fejlesztés megvalósítja az egyének teljesítményelőnyeit, de csak az utóbbi esetben lépik túl az előnyök a meglévő emberi képességeket.

Egy másik lehetséges megkülönböztetés a kognitív fejlesztés viszonylag közvetlen vagy közvetett megközelítései között van. Közvetlennek tekintjük a módszertanokat és a technológiákat, ha azok azonnal a tanulás, az észlelés, a megismerés vagy az érzelem mögött álló strukturális vagy funkcionális mechanizmusokat és folyamatokat célozzák meg. A közvetlen fejlesztéses megközelítések közé tartoznak a célzott képzési technológiák és módszerek. A közvetett javító megközelítések közé tartoznak a táplálkozási és az étrendi beavatkozások, az ellenálló képesség és a csapatmunka képzése, a perifériás idegstimuláció, a testmozgás beavatkozásai és az alvás módosítása.

Az Amerikai Egyesült Államok hadereje például már több évtizede sikeres tevékenységet folytat a kutatás-fejlesztés terén, ami közvetlenül a kognitív teljesítmény fokozására irányul, és igyekszik erősíteni az olyan folyamatokat és állapotokat, mint az éberség, a helyzetfelismerés, a döntéshozatal és az érzelmek szabályozása. Különösen három terület kapott jelentős figyelmet a katonai kutatási és képzési összefüggésekben. Ezek a vizsgált területek, amelyeknél a későbbiekben áttekintjük az MI alkalmazásának lehetőségeit is, az alábbiak:

- a célzott képzési technológiák és módszerek;

- a transzkraniális elektromos agyi stimuláció és a valóság fokozásának kérdései;

- a kapcsolódó kognitív rehabilitációs kutatások áttekintése.

\footnotetext{
${ }^{16}$ Nick Bostrom - Anders Sandberg: Cognitive Enhancement: Methods, Ethics, Regulatory Challenges. Science and Engineering Ethics, Vol. 15, 19. 06. 2009., 311-341. https://link.springer.com/article/10.1007/s11948-009-9142-5 (Letöltés időpontja: 2021. 01. 06.)
} 
A célzott képzés célja, hogy közvetlenül befolyásolja a tudás vagy a készségek elsajátításának mértékét akár egy speciális területen (például megtanulják, hogyan kell felszerelni egy málhamellényt, karbantartani a fegyvert, ellenőrizni az ejtőernyőt, programozni a rádiót stb.). A kognitív és az eljárási készségek elsajátítására, gyakorlására és azoknak a speciális területeken történő tanulás javításának alkalmazásához már rendelkezésre áll különböző szakirodalom, amely felhasználható a katonai képzések során is. Ezek közül néhány példa a közvetlen megközelítési módszerekből:

- gazdag multimédiás tanulási tapasztalatok, amelyek növelik a tananyagok realizmusát és élénkségét, többszenzoros modalitást integrálnak, átfogóbb és rugalmasabb mentális modelleket építenek, valamint több lehetséges utat kínálnak a visszakereséshez; ${ }^{17,18}$

- validált oktatási stratégiák, amelyek elősegítik a memória megszilárdulását és továbbfejlesztését, ideértve a visszakeresési gyakorlatot, az elsajátításhoz szükséges tanulást, az osztott tanulást és a nehézségek bevezetését a tanulásba a hosszú távú memória javítása érdekében; ${ }^{19,20,21}$

- szimulációalapú képzés, amely valós képzési feladatokat és környezetet emulál, hogy növelje a realizmust és a felhasználói elkötelezettséget a speciális képzési tapasztalatok terén, valamint megkönnyítse az ismeretek átadását, ${ }^{22}$

- visszacsatolási módszerek (beleértve a biofeedbacket, ${ }^{23}$ a neurofeedbacket ${ }^{24}$ és a szemmozgás modellezését), amelyek ösztönzik a kritikus önreflexiót és növekedést, a hibák felismerését és javítását, valamint a mélyebb megértést. ${ }^{25,26}$

${ }^{17}$ Paul N. Blankenbeckler et al.: Designing interactive multimedia instruction to address soldiers' learning needs. United States Army Research Institute for the Behavioral and Social Sciences, Research Report 1979, 12. 2014. https://apps.dtic.mil/sti/pdfs/ADA616380.pdf (Letöltés időpontja: 2021. 06. 29.)

${ }^{18}$ Charlotte Campbell et al.: Interactive multimedia instruction for US Army training. In: Thomas Reeves - Shirley Yamashita (eds.): Proceedings of E-Learn 2006 - World Conference on E-Learning in Corporate, Government, Healthcare, and Higher Education. Honolulu, 2006, 1105-1110. https://www.learntechlib.org/p/23854/ (Letöltés időpontja: 2021. 01. 05.)

19 Tad T. Brunyé et al.: Verbal long-term memory is enhanced by retrieval practice but impaired by prefrontal direct current stimulation. Brain and Cognition, Vol. 128, 2018, 80-88. https://www.sciencedirect.com/science/article/ abs/pii/S0278262618302628?via\%3Dihub (Letöltés időpontja: 2021. 01. 05.)

${ }^{20}$ Tad T. Brunyé et al.: Retrieval practice enhances near but not far transfer of spatial memory. Journal of Experimental Psychology: Learning Memory and Cognition, Vol. 46, 2020, 24-45. https://oi.apa.org/doiLanding?doi=10.10 37\%2Fxlm0000710 (Letöltés időpontja: 2021. 01. 05.)

${ }^{21}$ Randall D. Spain et al: Current trends in adaptive training with military applications: An introduction. Military Psychology, Vol. 24, Issue 2, 2012, 87-95. https://www.tandfonline.com/doi/full/10.1080/08995605.2012.6769 84 (Letöltés időpontja: 2021. 01. 05.)

${ }^{22}$ Stephanie J. Lackey et al.: A study in training effectiveness. Interservice/Industry Training, Simulation, and Education Conference (I/ITSEC), Orlando, 2014. https://www.researchgate.net/publication/292984866 Virtual World_Room_Clearing_A_Study_in_Training_Effectiveness (Letöltés időpontja: 2021. 01. 05.)

${ }^{23}$ A biofeedback olyan módszereket jelent, amelyek élettani müködések tudatosítására irányulnak - mindenekelött olyan készülékekkel, amelyek információt szolgáltatnak ezeknek az élettani rendszereknek a müködéséről - az akaratlagos befolyásolás képességének megszerzése céljával.

${ }^{24}$ A neurofeedback egy noninvazív, fájdalommentes agytornatechnika. A módszert a NASA fejlesztette ki negatív stresszhatások kiküszöbölésére, a psziché és a teljesítőképesség javítására.

${ }^{25}$ Mark A. McDaniel - Gilles O. Einstein: Material appropriate difficulty: A framework for determining when difficulty is desirable for improving learning. In: Alice F. Healy (ed.): Decades of behavior. Experimental cognitive psychology and its applications. American Psychological Association, 2006, 73-85. https://psycnet.apa.org/doiL anding?doi=10.1037\%2F10895-006 (Letöltés időpontja: 2021. 01. 05.)

${ }^{26}$ John A. Swets - Robert A. Bjork: Enhancing human performance: An evaluation of "new age" techniques considered by the U.S. Army. Psychological Science, Vol. 1, Issue 2, 1990, 85-96. https://journals.sagepub.com/ doi/10.1111/j.1467-9280.1990.tb00074.x (Letöltés időpontja: 2021. 01. 05.) 
Míg a célzott kiképzési megközelítéseket az Amerikai Egyesült Államok hadserege több évtizede alkalmazza, a kialakuló multimédiás oktatási stratégia és a visszacsatolási megközelítések fokozatosan beépülnek az alap- és haladó képzési kontextusba, amint azok elérhetővé válnak és érvényesülnek. A már említett CCDC SC MASTR-E program egy alkalmazott kutatási projektet tartalmaz, amely a tanulási és az oktatási tudományok legjobb elveit közvetlenül a hadsereg oktatási helyeire közvetíti.

A noninvazív agyi stimuláció $\left(\mathrm{NIBS}^{27}\right)$ célja a kognitív teljesítmény fokozásában szerepet játszó specifikus agyi régiók aktivitásának közvetlen megcélzása és megváltoztatása számos feladat és folyamat során. Az amerikai hadsereg számos NIBS-módszert azonosított és vizsgált a teljesítménynövelö tulajdonságaik miatt, különös tekintettel a transzkraniális egyenáramú stimulációra ${ }^{28}\left(\mathrm{tDCS}^{29}\right)$ és a transzkraniális váltakozó áramú stimulációra $\left(\mathrm{tACS}^{30}\right)$. Ez a két technika magában foglalja az alacsony intenzitású (közvetlen vagy váltakozó) elektromos áram adagolását az agykérgi (kortikális) területekre a fejbőr felületén elhelyezett két vagy több elektróda segítségével. Az amerikai hadsereg által vizsgált, megcélzott agyi régiók és mentális folyamatok közé tartozik a dorzolaterális prefrontális kéreg ${ }^{31}$ például az emlékezet fokozása érdekében. A további kutatási irányok között szerepel a jobb mediális temporális lebeny stimulálása a navigáció és a térbeli memória fokozásához, a jobb oldali orsó alakú agytekervény (fusiformis gyrus) az arcmemória javításához és a bal frontopoláris régió a kreatív problémamegoldás fokozásáért. Általánosságban elmondható, hogy a hadsereg kutatása ezen a területen viszonylag alapkutatásként kezdődött, és az utóbbi években egyre bővül és egyre inkább alkalmazható. Például a MASTR-E program tartalmaz egy alkalmazott kutatási projektet, amely a bizonytalanság és a stressz körülményei között vizsgálja a prefrontális tDCS hatását a döntéshozatalra és a lövészteljesítményre. Ezek az általános hatások arra engednek következtetni, hogy az NIBS kutatásai rendkívül ígéretesnek tünnek az észlelés, a megismerés és az érzelemszabályozás számos aspektusának fokozására, amelyek kritikusak a katonai személyzet müködéséhez.

A valóság fokozásának (Reality Augmentation) célja, hogy a katonáknak kontextusspecifikus és a feladatra vonatkozó információkat nyújtson olyan módon, amely nem feltünően, vagyis intuitív módon integrálódik a meglévő berendezésekbe. A vizuális és a multimodális érzékelés bővítése releváns, időszerü és cselekvésre alkalmas információkkal közvetlenül befolyásolhatja a katona feladat-végrehajtásának több aspektusát. Két példán keresztül nézzük meg, hogy ez a cél a katonai feladatok során hogyan realizálható.

A területi tudatosság növelése érdekében a kibővített valóság rendszerei térinformációkkal szolgálhatnak, amelyek közvetlenül segítik a lokalizációt, a tájékozódást, az útvonaltervezést és a navigációt. A fokozott lokalizáció valós idejü rácskoordináták vagy minitérkép-jelölések frissítésével érhető el grafikus átfedések segítségével. A fokozott tájékozódást úgy lehet elérni, hogy „beúszó” jelzőfényekkel mutatjuk meg a kiemelt tereptárgyak irányát és távolságát, valamint az ismert baráti és ellenséges egységeket. Ennek pozitív hatása lehet a bizonytalanság és a szorongás csökkentésére, valamint a pontosság és a döntéshozatali sebesség növelésére a döntéshozatalok során. A továbbfejlesztett útvonaltervezés interaktív, háromdimenziós terepábrázolások biztosításával érhető el, tanulmányozható és manipulálható az egyének és az együttmüködő csapatok által.

\footnotetext{
${ }^{27}$ Noninvasive Brain Stimulation.

${ }^{28}$ A neuromoduláció egy olyan formája, amely állandó alacsony egyenáramot használ a fej elektródjain keresztül.

${ }^{29}$ Transcranial Direct Current Stimulation.

${ }^{30}$ Transcranial Alternating Current Stimulation.

${ }^{31}$ Elsősorban az agyban a parietális kéreg felől érkező rövid távú téri memóriafunkciókat biztosító pályák fogadási helye.
} 
A kiterjesztett valóság javíthatja a fenyegetések észlelésének, osztályozásának és sikeres kezelésének a képességét is. A fenyegetések fokozott felderítését olyan rendszerek kínálják, amelyek képesek jelezni és ráirányítani a felhasználó figyelmét a lehetséges potenciális fenyegetésekre. Fokozott besorolást kínálnak azok a rendszerek, amelyek képesek észlelni a cél tulajdonságait, ezzel segítenek besorolni egy kialakuló fenyegetés felbukkanását és nagyságát, jellemzően gépi látás és mesterséges intelligencia segítségével. Célzott célmegkötés valósítható meg valós idejü információkkal a környezeti információkról és megjelölhető a célok tömegközéppontja is. ${ }^{32}$ A kiterjesztett valóság nagy lehetőségeket kínál a vizuális és multiszenzoros észlelés, valamint a döntéshozatal javítása területén, de a kihívások közé tartozik a figyelemelterelés, a mentális terhelés, a vizuális „elzáródás” rövid és hosszú távú kockázatainak a vizsgálata is.

A kognitív készségek rehabilitációja olyan terápiás megközelítéseket foglal magában, amelyek vizsgálatára a hadseregek jelentős befektetéseket fordítanak. Például több évtizedes kutatás során megvizsgálták az enyhe és a mérsékelt traumás agysérülések $\left(\mathrm{TBI}^{33}\right)$ megelőzését, felmérését és kezelését, amelyek rövid és hosszú távú kognitív károsodásokkal is társulnak, például figyelem, memória, nyelv és problémamegoldás képessége.

A közvetlen megközelítés kiegészítéseként az amerikai hadsereg számos közvetett kognitív teljesítménynövelési technikát is kutatott. A közvetett technikák általában széles kognitív és szociális-érzelmi készségfejlesztést, valamint a biológiai rendszerek, például a bél, az agy és a perifériás idegrendszer közötti interaktív kapcsolatokat használják fel. Itt tágabb értelemben öt közvetett javító kategóriát vehetünk figyelembe:

- a táplálkozási és étrendi beavatkozást;

- az ellenálló képességet és a csapatmunkát;

- a perifériás idegstimulációt;

- a testmozgást;

- és az alvásmódosítást.

A táplálkozási és étrendi beavatkozás a pótlási vagy táplálkozási szokások rövid vagy hosszú távú módosítását foglalja magában, hogy közvetett módon befolyásolja az izgalmi állapotot, az éberséget, az irányítási képességet, a kreatív problémamegoldást és/vagy az érzelmek szabályozását. A pszichostimuláns koffein formájában történő fogyasztása rendkívül gyakori a katonai személyzetnél, és ez a központi és a perifériás idegrendszeri aktivitás megváltoztatására szánt kiegészítések egyik példája. Az amerikai hadsereg megvizsgálta számos stimuláns, a koffein, az amfetamin, a modafinil, a nikotin és a deprenil hatását a kognitív teljesítményre. Ezek közül több azt ígéri, hogy átmeneti izgalmat és éberséget biztosít, és javíthatja a katonák kognitív teljesítményét az alváskorlátozás és a nélkülözés körülményei között. A koffein fokozhatja a vizuális éberséget és a végrehajtó ellenőrzés szempontjait az alacsony vagy magas fogyasztási szokásokkal rendelkező katonákban. A koffein kognitív hatásainak hátterében álló mechanizmust általában egy vagy több neurotranszmitter-rendszer (például adenozin, dopamin és noradrenalin) modulációja révén megnövekedett központi és perifériás idegrendszeri izgalomnak tekintik.

Az Amerikai Egyesült Államok hadserege a Védelmi Egészségügyi Program kezdeményezését vezeti, amely a katonák bélmikrobiomját - a belekben élö mikrobákat - manipulálja polifenolos (antioxidánsok) táplálás révén, valamint a kognitív és a fizikai teljesítményt méri

\footnotetext{
${ }^{32}$ A MASTR-E program például tartalmaz egy alkalmazott kutatási projektet, amely a kiterjesztett valóság hasznosságát vizsgálja ezeknél a katonai feladatoknál.

${ }^{33}$ Traumatic Brain Injury.
} 
nagy magasságban (szimulációs környezetben). A magaslati környezetek különös kihívást jelentenek a katona teljesítménye szempontjából, tekintettel az alvásra, az érzelmekre, a megismerésre és a fizikai képességekre gyakorolt káros hatásokra. A kutatási eredményeknek megvan a lehetősége a bélmikrobiom- és metabolitprofilok meghatározására, amelyek a valós teljesítményhez szükségesek a valós taktikai környezetben, és irányíthatják a táplálkozást vagy a táplálékkiegészítést, amely szükséges a kognitív teljesítmény közvetett megváltoztatásához. A prebiotikus - emészthetetlen növényi rostok, amelyek serkentik a bélbaktériumok szaporodását - és a probiotikus - a bél mikrobiota összetételének megváltoztatására szánt élő baktériumtörzsek - táplálékkiegészítések egyértelmüen hatással vannak az emberi bél mikrobiomjára, valamint - valószínűleg kisebb mértékben, de - befolyásolhatják az emberi kognitív teljesítményt.

Az ellenálló képesség, a kognitiv és a csapatmunka képességek képzése magában foglalja a kognitív képességek területének általános fejlesztését, amelyek kihatnak a stresszhelyzeti kognitív teljesítmény fokozására egy csapat részeként. Az amerikai hadsereg régóta kutatja, fejleszti és alkalmazza a rugalmasságot és az éberségi képzést. Az átfogó katona és családi fitnesz $\left(\mathrm{CSF}^{34}\right)$ programmal az ellenállóság mesterképzés $\left(\mathrm{MRT}^{35}\right)$ részeként a hadsereg arra törekszik, hogy növelje a katonák szellemi, fizikai, érzelmi és viselkedési képességét, hogy szembenézzenek a nehézségekkel és megbirkózzanak velük, alkalmazkodjanak a változásokhoz, gyorsan felépüljenek és tanuljanak. A hivatalos ellenállóság-képzés magában foglalja az MRT alapvető kompetenciáinak megtanulását és gyakorlását. A tréning célja a mentális erőnlét növelése, az optimális teljesítmény fenntartásának képessége a stressz alatt, a mások hatékony vezetése és a kihívásokkal teli célok elérése. Az amerikai hadsereg az éberségen alapuló gyakorlatokat is feltárta, ideértve az éberségen alapuló elmefitneszedzéseket $\left(\mathrm{MMFT}^{36}\right)$ és a pozitív érzelemellenálló képesség edzését $\left(\mathrm{P}-\mathrm{ERT}^{37}\right)$.

Az amerikai hadsereg kifejlesztette a Squad Overmatch programot is, hogy tantermi, virtuális és élő gyakorlatokon keresztül fokozza a készültséget és az ellenálló képességet, lehetővé téve a katonák és vezetők számára, hogy optimalizálják a személyes felkészültségüket és teljesítményüket bizonytalan és tartós veszélyhelyzetben. A továbbfejlesztett teljesítmény- és rugalmassági edzés lehetővé teszi a hatékony taktikai döntéshozatalt, és stresszes körülmények között küzd a harci sebesültek ellátásáért, ami maximalizálja az osztag sikerét és csökkenti a megelőzhető harci halált. A hadsereg kampányának része a teljesítményt befolyásoló egészségtelen stressz megelőzése. Erre a kampányra válaszul a Squad Overmatch program helyszíni kísérletet végzett, hogy tesztelje az innovatív, integrált képzési megközelítés hatékonyságát a csapatmunka, az ellenálló képesség és a helyzetismeret javítása érdekében, valamint csökkentse a stresszt, miközben taktikai harci sebesültellátást végez. A résztvevők a képzést hagyományos tanteremben (stand up előadás), virtuális környezetet szimuláló csapatképzésen (Virtual Battlespace III) és élö képzési gyakorlatokon keresztül kapták meg (szereplőkkel és a legkorszerübb szimulációs technikákkal).

\footnotetext{
${ }^{34}$ Comprehensive Soldier and Family Fitness.

${ }^{35}$ Master Resilience Training.

${ }^{36}$ Mindfulness-based Mind Fitness Training.

${ }^{37}$ Positive Emotion Resilience Training.
} 


\section{A KATONAI KUTATÁSOK KIHÍVÁSAI}

Az amerikai hadsereg és a közös szolgálatok folyamatosan igyekeznek versenyelőnyt szerezni a potenciális ellenfelekkel szemben, és számos kognitív fejlesztési stratégiát fontolgatnak a katonaspecifikus eredmények javítására, mint például a fenyegetés észlelése, a döntéshozatal, a helyzetfelismerés gyorsítása és az érzelmek szabályozása. A versenyelőny megszerzéséhez egyre szélesebb körben használják az MI-ket. E stratégiák közül sokat a védelmi laboratóriumokban dolgoznak ki, és helyszíni kiképzési gyakorlatokon validálnak. Ennek eredményeként a katonai egységek és az érdekelt felek számára belső jelentéseket készítenek a tudományos szakirodalom terjesztése nélkül. Ezért kihívást jelent megérteni a vizsgált specifikus módszertanokat, valamint az ebből eredő teljesítménynövekedések sajátosságát, megbízhatóságát és robusztusságát. A jelenlegi tudományos szakirodalom azonban szilárd alapot nyújt az alapvető mechanisztikus megértésekhez, és megvizsgálja a közvetlen és a közvetett fejlesztési stratégiák hatékonyságát korlátozott laboratóriumi körülmények között és feladatokban. Ezek a katonai kontextusban elvégzett feladatok kapcsán végzett kutatások az általánosítás szintjétől függetlenül erős alapot nyújtanak a feltörekvő technológiák és módszerek alkalmazásához a teljesítmény növelésére az alkalmazott összefüggésekben, például iskolai tanulás, speciális készségfejlesztés, misszió során tervezés és gyakorlatok, valamint müveletek.

A kognitív teljesítmény fokozására nagyon változatos módszereket alkalmazhatunk, és az amerikaiaknál már eredmények is mutatkoznak. Mindegyik megközelítés az észlelési, a kognitív és az affektív folyamatok egy részcsoportját célozza meg, és ily módon sajátos korlátai és kihívásai vannak a megvalósítás szempontjából. Érdemes megfontolni számos további vizsgálatot, amelyek befolyásolják a fejlesztési technikák hatékonyságát és végső alkalmazását katonai kontextusban.

Jelenleg még nem ismert, hogy milyen kompromisszumok vannak egyes teljesítmények javítása és ugyanakkor más teljesítmények esetleges csökkenése között. Ez különösen vonatkozhat az agystimulációs megközelítésekre, amelyek megváltoztatják az anyagcsereerőforrások iránti igényeket az egyes agyi régiókban, esetleg csökkentik azok elérhetőségét más agyi régiók számára, amelyekre a feladatok teljesítésekor támaszkodhatunk. Ez a tény a missziós feladatok szempontjából kritikus lehet. Az egyének szintjén bekövetkező kompromisszumok mellett a csapatok szintjén is érdemes figyelembe venni a kompromisszumokat a teljesítmények terén. Lehetséges például, hogy néhány csapattag teljesítményének növelése a fokozott elvárások miatt akaratlanul negatívan befolyásolhatja a csapat összteljesítményét. Ezzel szemben lehetséges, hogy az addig gyengébben teljesítő csoporttagok fokozott motivációt tapasztalhatnak a nagy teljesítményű csapattagok kapcsán. A szociál- és a kognitív pszichológia metszéspontjában végzett jövőbeni kutatásoknak figyelembe kell venniük azt a komplex csapatdinamikát, amely az individualizált fejlesztési megközelítések együttes alkalmazása esetén bontakozhat ki.

A katonaság általában a fejlesztési technikák alkalmazásával járó költségekre összpontosít, a közösségnek azonban figyelembe kell vennie a katona teljesítményének, egészségének és jólétének egyéb rövid és hosszú távú költségeit is. Az agyi stimuláció és bizonyos táplálékkiegészítők hosszú távú következményeit eddig például még nem teljes mértékben tárták fel, és káros hatással lehetnek az egészségre és az általános közérzetre. Néhány feltörekvő fejlesztési technika szabályozási szempontból ellentmondásos, ideértve az agy és a perifériás idegek stimulálását és a gyógyszerészeti kiegészítést, ami korlátozza a kutatás hatékonyságát és az azonosított technikák lehetséges széles körü elterjedését. 
A figyelemfelkeltés és a csapatmunka gyakorlásán kívül a legtöbb fejlesztési technikát konkrét feladatok (azaz területspecifikus) és egyéni teljesítmény szintjén vizsgálják, korlátozva annak megértését, hogy az ilyen technikák miként változtathatják meg a csoportban és a sokkal összetettebb csoportcélok érdekében végzett feladatok esetében. Míg a katonai állománytól elvárják, hogy jártasságot szerezzen bizonyos feladatokban, de ezekre az ismeretekre nincs szükség más feladatokhoz, a jövőbeni katonai müveletekhez komplex kognitív folyamatokra (helyzetfelismerés, döntéshozatal, problémamegoldás) lesz szükség. A célzott képzési módszerek magas hatékonyságot mutatnak, de az általános kognitív képességek fejlesztése vonatkozásában viszonylag kevés a kutatás, és az eredmények sem eléggé meggyőzőek. Ez egy jövőbeni kutatási terület lehet, amelyet a hadseregnek folytatnia kell, valamint a katonai egységek csoportszintü szervezete és komplex, kollektív feladat-végrehajtása miatt nagyobb hangsúlyt kell fektetni a csapatszintü fejlesztésekre. A katonai környezetben végzett fejlesztési technikák valós eredményeinek előrejelzésében a csoport jellemzői valószínüleg értékes paraméternek bizonyulnak.

A feltörekvő fejlesztési kutatások viszont bebizonyítják, hogy egyetlen fejlesztési technika sem nyújt mindenki számára egyforma eredményt minden összefüggésben és feladatban. A valódi teljesítménynövelésnek meg kell haladnia az emberi kognitív képesség szempontjait, kiemelve az összehasonlítás alapjául szolgáló, pontos alap csúcsteljesítmény-mérések elérésének fontosságát. Ilyen intézkedések nélkül nehéz biztosítani a fejlesztési programok hatékonyságát, és megkülönböztetni az optimalizálást és a továbbfejlesztést, amelyek a további kutatást ösztönzik. Végül a fejlesztési technikák alkalmazásának a kiválasztása az oktatás és a müveletek során számos olyan kihívást jelent, amelyek irányítják és korlátozzák az eszközök tervezését és alkalmazását. Ezek magukban foglalják a megfelelő eszközhasználat és karbantartás egyedi képzési igényeit, a harctéri eszközök hálózati követelményeit, valamint a hordozható és a viselhető eszközökön vagy azok körül elhelyezett meglévő hardverrel és szoftverrel történő interakciót és integrációt. A kihívásokat és a feltörekvő technológiák és technikák lehetőségeit figyelembe véve több irányban lehetséges a kutatás. ${ }^{38}$

\section{ÖSSZEFOGLALÁS, KÖVETKEZTETÉSEK}

Az amerikai hadsereg több mint fél évszázada használja a kognitívteljesítmény-növelö technikákat és technológiákat, a gyógyszeripar, az étrend, az idegtudomány, az oktatás, a technológia és az alvással kapcsolatos területeken. A kutatások során új eszközként megkezdték az MI-k alkalmazását is. A legtöbb eddigi kutatás bebizonyította, hogy lehetséges a teljesítmény optimalizálása. A jelenlegi kutatások fó kérdése, hogy a speciális megközelítések vagy az új technológiák - elsősorban az MI - segíthetnek-e a katonáknak a teljesítményük fenntartásában stressz, fáradtság, alváshiány esetén. Természetesen már rendelkezésre áll számos gyógyszer, amely hatékonyan csökkenti a kognitív teljesítményre gyakorolt negatív hatásokat. A teljesítménynöveléshez az MI segítségével és folyamatos kutatással megkísérelhetjük az egyének és a csapatok csúcsteljesítményének mérését, majd a kapott új referenciaértéken felüli fejlesztési stratégiák kialakítását. Az ígéretes jövőbeli technikák közé tartoznak a multimodális, az adaptív és az egyénre szabott megközelítések, amelyek kihasználják a mesterséges intelligencia és az orvosbiológiai mérnöki területeken elért eredményeket. E területek

\footnotetext{
${ }^{38}$ Az Amerikai Egyesült Államok hadseregének ezen a területen folytatott kutatása - amelyröl a tanulmányban is szó volt - irányadó lehet más hadseregek számára is.
} 
és az emberi teljesítménynövelö kutatás közötti szimbiotikus kapcsolat alátámaszthatja az együttmüködésen alapuló, multidiszciplináris kutatás és fejlesztés fontosságát. A kutatás eredményei előkészítik az utat az egyre elfogadottabb, megbízhatóbb és erőteljesebb kognitív fejlesztési módszerek előtt, amelyek felgyorsítják az ismeretek és a készségek elsajátítását, javítják a helyzettudatosságot és a stressz alatt történő döntéshozatalt, valamint elösegíthetik a jövőbeli katonák versenyelőnyének megszerzését az ellenfelekkel szemben.

\section{FELHASZNÁLT IRODALOM}

Blankenbeckler, Paul N. - Graves, Thomas Rhett - Wampler, Richard L.: Designing interactive multimedia instruction to address soldiers'learning needs. United States Army Research Institute for the Behavioral and Social Sciences, Research Report 1979, 12. 2014. https://apps.dtic.mil/sti/ pdfs/ADA616380.pdf

Bostrom, Nick - Sandberg, Anders: Cognitive Enhancement: Methods, Ethics, Regulatory Challenges. Science and Engineering Ethics, Vol. 15, 19. 06. 2009., 311-341. https://link.springer.com/ article/10.1007/s11948-009-9142-5; DOI: 10.1007/s11948-009-9142-5

Brunyé, Tad T. - Brou, Randy - Doty, Tracy Jill - Gregory, Frederick D. - Hussey, Erika K. - Lieberman, Harris R. - Loverro, Kari L. - Mezzacappa, Elizabeth S. - Neumeier, William H. - Patton, Debra J. - Soares, Jason W. - Thomas, Thaddeus P. - Yu, Alfred B.: A Review of US Army Research Contributing to Cognitive Enhancement in Military Contexts. Journal of Cognitive Enhancement, Vol. 4, 12. 02. 2020., 453-468. https://link.springer.com/article/10.1007/s41465-020-00167-3; DOI: $10.1007 / \mathrm{s} 41465-020-00167-3$

Brunyé, Tad T. - Smith, Amy M. - Hendel, Dalit - Gardony, Aaron L. - Martis, Shaina B. - Taylor, Holly A.: Retrieval practice enhances near but not far transfer of spatial memory. Journal of Experimental Psychology: Learning Memory and Cognition, Vol. 46, 2020, 24-45. https://doi.apa. org/doiLanding?doi=10.1037\%2Fxlm0000710; DOI: 10.1037/xlm0000710

Brunyé, Tad T. - Smith, Amy M. - Horner, Carlene B. - Thomas, Ayanna K.: Verbal long-term memory is enhanced by retrieval practice but impaired by prefrontal direct current stimulation. Brain and Cognition, Vol. 128, 2018, 80-88. https:/www.sciencedirect.com/science/article/abs/pii/ S0278262618302628?via\%3Dihub; DOI: 10.1016/j.bandc.2018.09.008

Campbell, Charlotte - Cantrell, Glenn - Generalao, Timothy - Sawyer, Alicia - Takitch, James: Interactive multimedia instruction for US Army training. In: Reeves, Thomas - Yamashita, Shirley (eds.): Proceedings of E-Learn 2006 - World Conference on E-Learning in Corporate, Government, Healthcare, and Higher Education. Honolulu, 2006, 1105-1110. https://www. learntechlib.org/p/23854/

Lackey, Stephanie J. - Salcedo, Julie - Matthews, Gerald - Maxwell, Douglas: A study in training effectiveness. Interservice/Industry Training, Simulation, and Education Conference (I/ITSEC), Orlando, 2014. https://www.researchgate.net/publication/292984866_Virtual_World_Room_ Clearing_A_Study_in_Training_Effectiveness

McDaniel, Mark A. - Einstein, Gilles O.: Material appropriate difficulty: A framework for determining when difficulty is desirable for improving learning. In: Alice F. Healy (ed.): Decades of behavior. Experimental cognitive psychology and its applications. American Psychological Association, 2006, 73-85. https://psycnet.apa.org/doiLanding?doi=10.1037\%2F10895-006; DOI: 10.1037/10895-006

Dr. Négyesi Imre: A mesterséges intelligencia és a hadsereg. Hadtudomány, 2019/3., 71-79. https:// www.mhtt.eu/hadtudomany/2019/2019_3/2019eA\%20mesterséges\%20intelligencia\%20és\%20 a\%20hadseregek_Négyesi\%20Imre.pdf; DOI: 10.17047/HADTUD.2019.29.3.71 
Dr. Négyesi Imre: A mesterséges intelligencia és az etika. Hadtudomány, 2020/1., 103-113. http://mhtt. eu/hadtudomany/2020/2020_1szam/Hadtudomany_2020-1-szam.pdf; DOI: 10.17047/HADTUD. 2020.30.1.103

Dr. Négyesi Imre: A mesterséges intelligencia katonai felhasználásának társadalmi kérdései. Honvédségi Szemle, 2021/1., 133-144. https://kiadvany.magyarhonvedseg.hu/index.php/honvszemle/article/ view/199; DOI: 10.35926/HSZ.2021.1.10

Porkoláb Imre - Négyesi Imre: A mesterséges intelligencia alkalmazási lehetöségeinek kutatása a haderöben. Honvédségi Szemle, 2019/5., 3-19. https://honvedelem.hu/images/ media/5f2bd1646eeb8298912683.pdf

Spain, Randall D. - Priest, Heather A. - Murphy, Jennifer S.: Current trends in adaptive training with military applications: An introduction. Military Psychology, Vol. 24, Issue 2, 2012, 87-95. https://www. tandfonline.com/doi/full/10.1080/08995605.2012.676984; DOI: 10.1080/08995605.2012.676984

Swets, John A. - Bjork, Robert A.: Enhancing human performance: An evaluation of "new age" techniques considered by the U.S. Army. Psychological Science, Vol. 1, Issue 2, 1990, 85-96. https://journals. sagepub.com/doi/10.1111/j.1467-9280.1990.tb00074.x; DOI: 10.1111/j.1467-9280.1990.tb00074.x 